\title{
Suggested Methods for Rock Failure Criteria: General Introduction
}

\author{
R. Ulusay $\cdot$ J. A. Hudson
}

Published online: 3 July 2012

(C) Springer-Verlag 2012

In the application of rock mechanics to rock engineering design, one of the most important issues is the failure of rock: we wish to fail the rock during the excavation process; and then avoid failure of the completed structure. For this reason, the failure of rock has been one of the most important research subjects since the formation of the ISRM in 1962. However, over the years it has become difficult to decide on the best failure criterion to use in specific situations. The 'Mohr-Coulomb' and 'HoekBrown' are the most frequently used failure criteria-but both of these incorporate only the major and minor principal stresses, and not the intermediate principal stress. However, other criteria have been suggested over the years. The ISRM Commission on Testing Methods set out to prepare this document to provide guidance on the characteristics of the several existing failure criteria and suggest circumstances when they should be employed.

In the ISRM Suggested Methods published to date (Ulusay and Hudson 2007), there is explicit guidance on testing procedures. However, such explicit guidance is not appropriate for the application of a failure criterion because of all the many factors that can be involved in a particular potential rock failure circumstance, plus the individual requirements of the researcher or engineer. Accordingly, the Suggested Methods for failure criteria report on six

Please send any written comments on these ISRM Suggested Methods to Prof. R. Ulusay, President of the ISRM Commission on Testing Methods (Hacettepe University, Geological Engineering Department, 06800 Beytepe, Ankara, Turkey, E-mail: resat@hacettepe.edu.tr).

R. Ulusay $(\bowtie) \cdot$ J. A. Hudson

Geological Engineering Department, Hacettepe University,

06800 Beytepe, Ankara, Turkey

e-mail: resat@hacettepe.edu.tr failure criteria, presenting the background, formulation, related experimental data, advantages and limitations, plus recommendations. In addition, there is an extensive suite of key references. In this way, we hope that the publication of the Suggested Methods for Failure Criteria will assist readers' understanding of the failure criteria and hence enable them to make more informed and hence appropriate choices concerning which criterion to utilise in any given circumstances.

The individual Suggested Methods have been both written and reviewed by international authorities. We are especially grateful to Professors Bezalel Haimson and Antonio Bobet for taking the lead in the Working Group and to all the individual authors who are named in each Suggested Method.

\section{References}

Ulusay R, Hudson JA, ISRM (2007) The complete ISRM suggested methods for rock characterization, testing and monitoring: 1974-2006. In: Ulusay R, Hudson JA (eds) Commission on testing methods. International Society of Rock Mechanics. Compilation arranged by the ISRM Turkish National Group, Ankara, Turkey, $628 \mathrm{p}$ 